\title{
Aspects of eco-innovation during the pandemic in a global environment
}

\author{
Erika Loučanová ${ }^{1,{ }^{*}}$, Miriam Olšiaková ${ }^{,}$, Eva Drličková1, and Anna Dovčíková ${ }^{1}$ \\ ${ }^{1}$ Technical University in Zvolen, Faculty of Wood Sciences and Technology, Department of \\ Marketing, Trade and World Forestry, T. G. Masaryka 24, 96001 Zvolen, Slovakia
}

\begin{abstract}
Research background: The COVID-19 pandemic has significantly affected lives of every society. As a result of a pandemic, companies have to face the consequences and challenges associated with this situation, which also manifest in a global environment. The negatives caused by the pandemic began to appear in deglobalization trends, which required national economies to behave nationally in selected areas and seek solutions to address the negative impacts within their own possibilities. The pandemic has caused significant changes in the market, both on the part of sellers and buyers. Recently, their attention has been focused on the development of sustainability through the introduction of eco-innovation.

Purpose of the article: The paper deals with selected theoretical and practical aspects of eco-innovation during a pandemic in a global environment.

Methods: The data were obtained by a means of questionnaire and consequently evaluated by the chosen statistical methods.

Findings \& Value added: The results presented in the paper point to the deglobalization trend within the concept of socially responsible business based on the principles of sustainability as an integral part of the strategy based on the quote "Think Global, Act Local". The term "global" does not emphasize a global perspective, as we have understood them so far, but rather refers to the inclusiveness of the environment caused by a pandemic.
\end{abstract}

Keywords: deglobalization; eco-innovation; pandemic; sustainability

JEL Classification: $M 31 ; O 00 ; O 31$

\section{Introduction}

The success of a company in a global context determines the company's ability to respond promptly to change market conditions and its ability to meet customer needs. One way to achieve these goals is to innovate. It means to create new products and services that are genuine, different from other offers on the market and that meet market-relevant conditions

\footnotetext{
*Corresponding author: loucanova@tuzvo.sk
} 
(Dzian et al., 2019). There is a strong emphasis on innovation and its importance is constantly increasing. A strong emphasis is also placed on sustainability associated with innovation (Dzian et al., 2019; Loučanová and Olšiaková, 2020). Effectiveness of innovation and efficient performance of organizations significantly depends on skills and abilities of employees to create, design and apply innovation, but on many other factors, too. We can say that globalization and the technological revolution increase and emphasize the importance of knowledge and innovation activities (Šoltés et al., 2020; Štofková Repková and Štofková, 2020; Tisdell, 2020; Mat'ová et al., 2020). On the other hand, one of the most influencing factors is the coronavirus COVID-19 pandemic that actually impacts our lives in various areas (Štofková Repková and Štofková, 2020).

The most important point is that it has significantly reduced (and disrupted) economic and social activity. Its negative effects have been mitigated to a certain extent by the availability of by the availability of advances in information and communication technology (Tisdell, 2020).

Regarding the trade, the COVID-19 pandemic has caused plenty of issues which businesses have to adapt and solve. Some companies have taken actions immediately, applying various intervention types. Their reactions to the new situation have significantly influenced their business, because they did not have much time to realize appropriate actions. Some companies had to succeed in the market with growing competition which was significantly represented by online stores. The crisis made them consider if they go out of business or permanently close a high proportion of physical stores. This decision meant that consumers will not be able to revert to former shopping habits. Moreover, COVID-19 pandemic is associated with various restrictions. Some countries regularized total lockdown strategies, others reduced the performance of businesses and services, and several countries established containment measures that significantly restricted the possibilities for people to leave their homes (Pantano et al., 2020). The changes were subsequently reflected not only in the way certain services and sales were provided, but also in the way consumers made their purchasing decisions.

For that the research focuses on the aspects of eco-innovation during the pandemic in a global environment.

\section{Methodology}

The research deals with the perception of ecological innovations and it was realized by the Kano model. Kano model aims to capture customers' opinion according to the requirements of an observed object Kano model is based on a survey using a Kano questionnaire. This questionnaire is constructed through pairs of customer requirement questions. Each question consequently has two parts: how do you feel if that feature is present in the product (functional form of the question), and how do you feel if that feature is not present in the product (dysfunctional form of the question). These pairs of positively and negatively conceived statements regarding the performance of monitored parameters, in this case ecological innovations - price products, quality products and ecological innovations by products. We observed eco-innovation in a more detailed way in the following areas: Environmental product safety, The importance of eco-innovation, The origin of ecoinnovation, Slovak products with enviro brand, Ecological innovation, The concept of ecoinnovation, Availability of eco-innovation, Information on eco-innovation, Attractiveness of eco-innovation, Advertising of eco-innovation, The price of eco-innovation. According to the methodological approach respondents had an opportunity to respond every question (statement) on a scale from 1 to 5 representing strong agreement to strong disagreement with that question (statement). 
The sample of respondents was set at 740 respondents in Slovakia. The responses were evaluated according to the cross rule (Grapentine, 2015), making it possible to categorize functions of packaging in the research parameters according to how respondents perceived ecological innovation (Grapentine, 2015; Ducár et al., 2006; Loučanová et al., 2016; Loučanová et al, 2021; Rostášová et al., 2020):

- $\quad \mathrm{M}$ (must be requirements) - are obligatory requirements that customers consider as normal and are automatically expected and their fulfilment is reflected in customers' satisfaction.

- O (one-dimensional requirements) - are those product attributes that lead to fulfilment and satisfaction in the event of non-compliance to customers dissatisfaction but compared to the obligatory requirements customers automatically do not expect them.

- A (attractive requirements) - that have a clear impact on customers satisfaction because it is a requirement that customers did not expect, but it is attractive.

- $\quad \mathrm{R}$ (reverse requirements) - are contradictory, they bother customers, as they require some additional action from them.

- I (indifferent, irrelevant requirements) - are requirements which do not affect customers' satisfaction or dissatisfaction.

- $\quad \mathrm{S}$ - are sceptical, questionable requirement

The most numerous categories identified the attitude of respondents toward the examined parameter. Subsequently, the total strength of the parameter was determined according to equation (1) by Baier et al. (2020):

$$
\text { Total Strength }=(\# \mathrm{~A}+\# \mathrm{M}+\# \mathrm{O}) /(\# \mathrm{~A}+\# \mathrm{I}+\# \mathrm{M}+\# \mathrm{O}+\# \mathrm{Q}+\# \mathrm{R})
$$

The results of Kano model allows to divide the monitored ecological innovations into categories of mandatory, attractive, indifferent and reverse functions. In the next step the comparison obtained results from research conducted in 2019 and 2021 and on the basis of inductively deductive method, conclusions and discussion related to solved issues are formulated.

\section{Result and Discussion}

KANO model identified requirements of the ecological innovations among the monitored in the two years 2019 and 2021. The customer's requirements are represented in Table 1

The research of the preferences change of Slovak respondents related to ecological innovations during the pandemic (Table 1) points to significant changes in their preferences. Slovak respondents consider the price of products to be attractive. Their preferences remained the same during the pandemic but with higher strength. It means that the acceptable price has a clear impact on customers' satisfaction because it is a requirement that customers did not expect, but it is attractive.

Respondent perceive the price of eco-innovation in an opposite way.

The brand, the standards, green brand, Slovak products, Slovak products with green brand and advertising of eco-innovation are perceived as requirements. These product attributes lead to fulfilment and satisfaction of customers and in their dissatisfaction if they are not observed. This is the difference between one-dimensional and must-be requirements customers do not expect them automatically.

Originally, the attributes such as the brand, green brand and Slovak product with green brand did not affect respondents in Slovakia.

Attributes Slovak products and the perception of requirements remained the same, but their strength increased. 
Table 1. Research results

\begin{tabular}{|l|c|c|c|c|}
\hline \multirow{2}{*}{ Parameters } & \multicolumn{2}{|c|}{$\mathbf{2 0 1 9}$} & \multicolumn{2}{c|}{$\mathbf{2 0 2 1}$} \\
\cline { 2 - 5 } & $\begin{array}{c}\text { Require } \\
\text {-ments }\end{array}$ & $\begin{array}{c}\text { Total } \\
\text { Strength }\end{array}$ & $\begin{array}{c}\text { Require } \\
\text {-ments }\end{array}$ & $\begin{array}{c}\text { Total } \\
\text { Strength }\end{array}$ \\
\hline Price of products & A & 0.591371 & A & 0.691892 \\
\hline The brand & I & 0.545946 & O & 0.804054 \\
\hline The origin & I & 0.486486 & I & 0.667568 \\
\hline The standards & O & 0.553702 & O & 0.652703 \\
\hline Environmental product safety & I & 0.486486 & I & 0.543243 \\
\hline The importance of eco-innovation & I & 0.448486 & I & 0.543243 \\
\hline The origin of eco-innovation & I & 0.513973 & I & 0.522973 \\
\hline Green brand & I & 0.545946 & O & 0,670270 \\
\hline Slovak products & O & 0.618919 & O & 0.868919 \\
\hline Slovak products with green brand & I & 0.486486 & O & 0.582432 \\
\hline Ecological innovation & I & 0.486486 & A & 0.567568 \\
\hline Availability of eco-innovation & I & 0.440511 & I & 0.540541 \\
\hline Information on eco-innovation & I & 0.545946 & I & 0.636486 \\
\hline Advertising of eco-innovation & I & 0.545946 & O & 0.545946 \\
\hline The price of eco-innovation & R & 0.486486 & R & 0.486486 \\
\hline
\end{tabular}

Source: Own processing (2021)

The other examined attributes do not affect respondents. It means that they do not have a significant influence on their purchasing decisions. The most significant differences in the study of the perception of eco-innovation by Slovak respondents appeared in the brand, green brand, Slovak product with green brand and Slovak products.

Slovak product and Slovak product with green brand present performance attributes. As it is stated by Panda et al. (2020), the country of origin is significantly important to influence the level of concern among customers. The cognitive links relating to the brand image affect the trust and loyalty of the consumers (Bashir et al., 2020).

The occurrence of the COVID-19 brought significantly changed and restricted health care, economy, transportation, and also other areas in different industries and regions. At the macro level, the COVID-19 resulted in the worst global recession since 1930 (Shen et al., 2020). These restrictions have a strong impact on consumers and businesses (Pantano et al., 2020) and they signify the deglobalization trend within the concept of socially responsible business based on the principles of sustainability as an integral part of the strategy based on the quote "Think Global, Act Local". Based on these results and the definition of sustainable development as it is defined by the World Commission for Environment (Chabowski et al., (2011) there is a need to create and / or maintain dyadic consonance while respecting contextual needs (Cox, 1999; Darnall et al. 2008).

The term "global" does not emphasize a global perspective, as we have understood them so far, but rather refers to the inclusiveness of the environment caused by a pandemic, strengthening the local economy, local companies with increasing customer loyalty to local products, innovation and the environment. 


\section{Conclusion}

The COVID-19 pandemic has significantly affected lives of the society. Regarding the trade, the COVID-19 pandemic has caused plenty changes. The reactions of the companies to the new situation have significantly influenced their business attitude towards innovation and sustainability. Their decision meant that consumers will not be able to revert to former shopping habits. The changes were subsequently reflected not only in the way certain services and sales were provided, but also in the way consumers made their purchasing decisions. The results presented in the paper point to the deglobalization trend within the concept of socially responsible business based on the principles of sustainability as an integral part of the strategy based on the quote "Think Global, Act Local". The term "global" does not emphasize a global perspective, as we have understood it so far, but rather refers to the inclusiveness of the environment caused by a pandemic.

\section{Acknowledgements}

The authors would like to thank the Scientific Grant Agency of the Ministry of Education, Science, Research and Sport of the Slovak Republic and the Slovak Academy of Sciences, grant number 1/0674/19, "Proposal of a model for the eco-innovation integration into the innovation process of companies in Slovakia in order to increase their performance" and grant number 1/0666/19 "Determination of the development of a wood-based bioeconomy".

\section{References}

1. Baier, D., Rausch, T. M., \& Wagner, T. F. (2020). The Drivers of Sustainable Apparel and Sportswear Consumption: A Segmented Kano Perspective. Sustainability, 12(7), Art. No. 2788.

2. Bashir, S., Khwaja, M. G., Rashid, Z., Turi, J. A., \& Waheed, T. (2020). Green Brand Benefits and Brand Outcomes: The Mediating Role of Green Brand Image. SAGE Open, 10(3), 1-11.

3. Chabowski, B. R., Mena, J. A., \& Gonzales-Padron, T. L. (2011). The structure of sustainability research in marketing, 1958-2008: A basis for future research opportunities. Journal of the Academy of Marketing Science, 39, 55-70.

4. Cox, A. (1999). Power, value and supply chain management. Supply Chain Management, 4, 167-175.

5. Darnall, N., Jolley, G. J., \& Handfield, R. (2008). Environmental management systems and green supply chain management: Complements for sustainability? Business Strategy and the Environment, 18, 30-45.

6. Ducár, S., Naščáková, J., \& Malák, M. (2006). Návrh systému merania spokojnosti zákazníkov Kano modelom. Transfer inovácií, 9, 137-139.

7. Dzian, M., Paluš, H., \& Parobek, J. (2019). Global trends affecting the EU timber trade. 12th WoodEMA Annual International Scientific Conference on Digitalisation and Circular Economy: Forestry and Forestry Based Industry Implications (pp. 297-301).

8. Grapentine, T. (2015, April 30). Why the Kano model wears no clothes. Quirks Marketing Research Media. Quirks. https://www.quirks.com/articles/why-the-kanomodel-wears-no-clothes

9. Loučanová, E., \& Olšiaková, M. (2020). Logistics, eco-innovations and pandemic. Acta logistica: international scientific journal about logistics, 7(3), 187-193. 
10. Loučanová, E., Parobek, J., \& Kalamárová, M. (2016). The perception of respondents of packaging innovations in Slovakia. Arad - Economics Series, 26(3), 33-43.

11. Loučanová, E., Šupín, M., Čorejová, T., Repková-Štofková, K., Šupínová, M., Štofková, Z., \& Olšiaková, M. (2021). Sustainability and Branding: An Integrated Perspective of Eco-innovation and Brand. Sustainability, 13(2), Art. No. 732.

12. Mat'ová, H., Triznová, M., Kaputa, V., Šupín, M., Drličková, E., \& Krahulcová, M. (2020). Consumers - global citizens from the CSR 2.0 perspective. 19th international scientific conference globalization and its socio-economic consequences 2019 sustainability in the global-knowledge economy, SHS Web of Conferences, 74, Art. No. 04015.

13. Panda, T. K., Kumar, A., Jakhar, S., Luthra, S., Garza-Reyes, J. A., Kazancoglu, I., \& Nayak, S. S. (2020). Social and environmental sustainability model on consumers' altruism, green purchase intention, green brand loyalty and evangelism. Journal of Cleaner Production, 243, 1-11.

14. Pantano, E., Pizzi, G., Scarpi, D., \& Dennis, C. (2020). Competing during a pandemic? Retailers' ups and downs during the COVID-19 outbreak. Journal of Business research, 116, 209-213.

15. Rostášová, M., Pad'ourová, A., \& Čorejová, T. (2020). KANO model as a tool of effective customer satisfaction diagnostics of postal services. Entrepreneurship and Sustainability Issues, 8(2), 811.

16. Shen, H., Fu, M.., Pan, H., Yu, Z., \& Chen, Y. (2020). The impact of the COVID-19 pandemic on firm performance. Emerging Markets Finance and Trade, 56(10), 22132230.

17. Šoltés, V., Štofková, K. R., \& Lenko, F. (2020). Socio-economic consequences of globalization on the economic development of regions in the context of security. SHS Web of Conferences, 74, Art. No. 04026.

18. Štofková, K. R., \& Štofková, J. (2020). Use of Open Data in the Development of the Digital Economy in the Knowledge Society in the Era of Globalization. SHS Web of Conferences, 74, Art. No. 03008.

19. Tisdell, C. A. (2020). Economic, social and political issues raised by the COVID-19 pandemic. Economic Analysis and Policy, 68, 17-28. 